\title{
5 FROM PEACE TO PROGRESS
}

\section{Bert Jenkins}

Following the completion of Phase 1 of the Strengthening Communities for Peace (SCP) project, Leitana Nehan obtained funding for a second phase of the project with the same name but subtitled 'From Peace to Progress'. Phase 2 ran over a period of 13 months between January 2003 and February 2004. Like Phase 1, Phase 2 emphasised personal development, particularly Integral Human Development (IHD), but also stressed community development through the strengthening of civil society and good governance at both the community and state levels (Cox 2004b). This emphasis had potentially important consequences for Bougainville, which was preparing at the time to become an autonomous region of Papua New Guinea under a new constitution. The main challenge in Phase 2 was not merely meeting set targets in SCP but also working in a gender sensitive way at all levels of activities that Leitana Nehan conducted. As with Phase 1, Phase 2 ran in parallel to other activities that supported the overarching project objective of 'advancing the role of women in society'.

\section{ASSOCIATED ACTIVITIES THAT SUPPORTED SCP OBJECTIVES}

During the period 2003-04, Leitana Nehan staff and volunteers were involved in a range of activities that directly or indirectly contributed to the goals of SCP Phase 2. Leitana Nehan met with various organisations in Bougainville to promote arms disposal in March 2003 (LNWDA 2003b). The Bougainville Alliance of 
Community Development Agencies and the Buka District Council of Women also were present at these deliberations. These meetings and advocacy activities were possible because the executive director, Helen Hakena, was closely associated with the Buka District Council of Women and was a prominent chief with authority to discuss women's issues and the peace process with respect to her matrilineal connections in North Bougainville. ${ }^{1}$ This authority made it possible for her to facilitate these meetings herself. A commitment to the ceasefire, the disposal of arms and a culture of peace were all essential preconditions for the peace-building work that Leitana Nehan was carrying out in Bougainville through SCP.

In March 2003, Helen toured Australia with the IWDA, talking to various women's groups about Leitana Nehan's work. This was part of Leitana Nehan's obligations as a recipient of the Millennium Peace Prize. In July 2003, Helen spoke at a Peace Symposium at the University of New England in Armidale about women's suffering in Bougainville (LNWDA 2003b). In September 2003, Helen was invited to Port Moresby to address a conference on 'women's rights', where she spoke about violence against women in the context of the plight of women during armed conflicts and in post-conflict situations (LNWDA 2003b). These opportunities allowed Helen, as Executive Director of Leitana Nehan, to promote and publicise the organisations work in Bougainville to an international audience.

In October 2003, Helen provided training for a World Vision project on 'Water Sanitation', a serious community development and public health issue, where she focused on issues of 'gender and development' (Hakena 2004).

Apart from being the executive director of Leitana Nehan, Helen held other important positions of responsibility. By the end of 2004, Helen Hakena was the secretary of the PNG Community Development Scheme (CDS), a member of the Provincial Education Board, and chair of the Provincial Literacy Programme.

In March 2003, George Lesi, the assistant executive director, was invited to provide input to a joint Provincial Government meeting on the 'recognition of women in the draft constitution' (LNWDA 2003b:n.p.). George was also invited to address important meetings 
that involved the community, civil society agencies, private companies and the government. In July 2003, he represented Leitana Nehan in speaking engagements at the PNG Islands Development Forum and the NGO Mining Conference (LNWDA 2003b). Another valuable service that George undertook was to assist in data collection for a Small Arms Survey project on gun-running in Papua New Guinea, which showed how weapons left Bougainville after the conflict and ended up in the Southern Highlands of Papua New Guinea (Alpers 2005). Leitana Nehan also sent him to attend professional development courses overseas, including a human rights training workshop in Thailand in 2003. ${ }^{2}$ Human rights issues, particularly for women and children, were an important focus of the SCP project.

Another Leitana Nehan workshop that had a major impact on women's lives was a seven-day training course for fifteen village birth attendants on the remote atoll of Nissan held in November 2003 (see box below). The course was coordinated by Agnes Titus and delivered by Cathleen Loadsman.

\section{SCP PHASE 2 PROJECT DESIGN AND ORGANISATION}

Whereas there were 10 team leaders and 40 volunteer assistants in SCP Phase 1, Phase 2 saw these numbers increase to 13 team leaders and 78 volunteers, a total of 91 individuals. The 13 teams were located in Nissan, Buka, Selau/Suir, Tinputz, Wakunai, Paruparu, Buin, Siwai, Bana, Northwest, Manatai/Torau, Koromira/Koianu and Torokina. The three new teams were located at Torokina in the west, and Koramira/Koianu and Manetai/Torau in the coastal districts of the central-southeast part of Bougainville Island. Although the new teams had commenced relatively late and only as Phase 1 neared completion, they were still active at the end of Phase 2. Nine teams were active on mainland Bougainville at the beginning of Phase 2; two additional teams-Bana from the southwest and a generic team from the Northwest-became active in the later stages of Phase $2 .^{3}$ Although these teams had been identified early on in SCP, they were relatively slow to develop, and this late start meant that training activities planned for team leaders, volunteers and community representatives had to be repeated and fast-tracked. Experienced staff 


\section{Box 5.1 Saving mothers' and babies' lives on Nissan Atoll Agnes Titus}

I got on the small Airlink plane at Nissan airport to go to Buka for a Leitana Nehan review in early 2003. On the flight, which had originated in Rabaul, was Cathleen Loadsman, a trained nurse, who was working in Arawa, and was involved in the village birth attendants' training on mainland Bougainville and in other parts of Papua New Guinea. We got talking about the state of affairs of women in Nissan and I recounted a recent incident of a mother giving birth in a canoe. I told Cathleen that I had been the President of the Tungol Catholic Women's Association since 1992, and that safe motherhood had always been an issue. There had been numerous instances where mothers gave birth in the villages, only trying to get to a health facility in emergencies. Many women had given birth in trucks, boats or under trees on their way to a health facility.

Nissan has one health centre and six aid posts. Because of the difficulties families face, such as a general lack of money, especially for transport and health facility fees, I made the request to Cathleen to try and find some funds to train the Nissan traditional birth attendants. She found some money, and the training was undertaken from 1-7 November 2003. At the closing ceremony, the women from the villages came together at Tungol and put on dances and sang in thanksgiving to the facilitators and coordinator for bringing home to them one answer to their issues, and saving their lives.

The three facilitators stayed at my home, and every morning, my husband Michael took us by boat across to Tungol Catholic Mission where the training was being held, and picked us up in the afternoon. The participants were accommodated at the mission. While on Nissan, Cathleen saw a young girl named Rose who was a victim of violence, unmarried and pregnant. Cathleen found that she had an enlarged spleen, and advised her to go to the health centre when she was ready. Just seven days after the workshop had finished, and after Cathleen had gone back home to her job at Prince Albert Hospital in Sydney, Cathy Rangai, who had just done the training, was called, along with the health worker at Mapiri aid post, Romanus. I also went along to help out if needed. To our amazement, Rose delivered normally a beautiful girl, which was named after Cathleen Loadsman.

Was it worthwhile? Yes! The VBA course had many important outcomes

- Rose Mako and Magorina Tondiat went full swing immediately after the workshop to raise awareness of the people of Yotchibol village about their role as VBAs.

- Daling Ute attended to six pregnancies in Kulis village.

- Cathrine Miriki has attended to all the pregnancies in Tanaheran village. All were successful, including her own daughter's (Takaku). Takaku's pregnancy was quite a difficult one, and she had to go to the Tungol aid post. She was later referred to the Kalil Health Centre and Cathrine told me that she delivered her grandson herself. There was no nurse in attendance.

- Rose Kaes and Alberta Nemon accompanied their pregnant friends to Buka District Hospital when they developed complications, having been referred from the Kalil Health Centre in Nissan.

- Nerry Libika, who was a member of the SCP team on Nissan, arrived at an awareness workshop in New Camp very sleepy one day after being up all night helping a young girl give birth. She was a single girl, unsure, and very poor as well. She gave birth with Nerry's assistance by the light from a small bottle lamp, as no one had a torch.

- Many men have come to support the VBAs more. For example, Lisa Nicky's husband, Luis, is one of the proudest and best supporters of the VBAs. This is because he has witnessed the challenges Lisa encounters when delivering babies at their village in Balil. 'She is helping a lot of women, including difficult births', says Luis.

This is a beautiful story for me and the women of Nissan, because we are isolated and impoverished. But we have proven that skills training can make a difference in our lives: the village birth attendants are saving lives on Nissan. 
had to redouble their efforts to support and help the new teams catch up in terms of planning, project activities and training.

Each team had a team leader and six volunteers. At the start of Phase 2, one of these volunteers was either a counsellor with some basic training or assisted in collecting counselling information (LNWDA 2003b). Subsequently, however, all teams had trained counsellors and in some cases an additional trained assistant. Many of these counsellors were trained in basic counselling skills during Phase 2, when the bulk of the grassroots counselling and intensive interaction with community groups took place. ${ }^{4}$

Every team had the task of developing two 'community case studies' and were expected to visit these communities four times before the end of Phase 2 (LNWDA 2003b). This meant that they had to concentrate their efforts in a few communities. However, the teams were required to also visit three other communities at least twice, including among them a number of selected schools (LNWDA 2003b). Therefore Phase 2, unlike Phase 1, was more intensive in that each team had to spend more time in two out of five selected communities. Activities in communities that were visited only twice were similar to those carried out in Phase 1: an initial visit to raise awareness and a follow up visit to organise progress towards the development of local strategies. In Phase 2, the teams were trained to monitor progress in their case study communities in order to tailor appropriate violence-prevention strategies that specifically suited the prevailing conditions in a particular location (LNWDA 2003b). This flexibility in Phase 2 gave team leaders the opportunity to make independent decisions with regard to implementing changes on the ground, depending on their own assessment of a situation. It made sense to allow experienced team leaders to instigate informed decisions, and the flexibility also indicates that a degree of trust had been established in team leaders' capabilities. Team leaders were encouraged in Phase 2 to monitor field activities and document 'lessons learned' from case studies and community consultations. They could share these lessons with other teams during workshops and apply them in their deliberations with community groups during subsequent visits. 
The first few months of Phase 2 were spent training the teams in organisational capacity-building skills, community development, governance issues, monitoring and project planning. This training took place through the strategic planning and 'training of trainers' workshops (LNWDA 2003b). The teams spent the initial three months of Phase 2 locating suitable communities and schools for workshops and case studies. The teams that started late had some catching up to do before they commenced project work with their respective communities.

\section{ADVANCING THE PROJECT}

By the middle of 2003 the teams were noticing that a number of women who had learned about their rights were now seeking additional assistance, forming groups to support each other, and participating more in community workshops than they had in Phase 1 (LNWDA 2003b). Increased acceptance of women working in decision-making roles was also reported at the community level. In addition, women were accessing resources and opportunities with less difficulty. Furthermore, the teams reported a general acknowledgment in the communities of the positive role women had played in transforming society from a culture of violence towards one of peace (LNWDA 2003b).

Helen witnessed many examples of changed conflict resolution strategies resulting from the workshops in the communities. In one case, Helen, Delphine Lesi and Hazel Geto (a woman from Buka who wanted to see the work first hand) went to the village of Teabes in Tinputz district to conduct project monitoring. They had to travel by boat because there was a roadblock between Buka and Tinputz. When they arrived at the village at about $1.30 \mathrm{pm}$, the team volunteers (Fabian, Ezekial and Linus) and members of the community were already assembled for the follow-up workshop. Just before the workshop there had been a fight, and Helen suggested to the people that it might not be a suitable time to run the program. The chiefs, however, wanted it to go ahead because if it did not then the fights would continue; they also wanted to gain skills to deal with the drinking and drug-related problems prevalent in the area at the time. 
On the same day as the workshop, the people who had been fighting, who were from the village of Dios, returned by car. They were angry with a family in Teabes and they went into their house and vandalised the place. They broke all the plates, and smashed up the kitchen. The people wanted to retaliate, but the chiefs said, 'You've heard the awareness, there are better ways of solving this problem than fighting in return. We will have to find strategies to solve this problem'. Helen and her colleagues stayed into the evening, discussing the issue with the chiefs. The older chiefs chose some young chiefs to meet with the chiefs from Dios. As a result of this meeting, the chiefs from both areas agreed that instead of further retaliation, the young men who had done the damage would replace the utensils and rebuild the kitchen, and they did in due course.

This monitoring visit also provided an example of how certain cultural practices have impacted on the conduct of workshops in the villages. When Helen and her friends were introduced, chiefs from about 20 different villages were sitting in the front row on the ground, not on platforms. According to their custom, the visitors had to kneel on the ground to honour the chiefs. They had to remain kneeling while they introduced themselves, and when the volunteers started to talk about various issues such as women's and children's rights. When Helen was talking, the people, who were sitting on the ground behind the chiefs, had to strain their necks to see her, because she was still kneeling down. Then Helen said, 'is it okay if we stand up? There are plenty of people here who can't see us and its good if they can see our faces while we are speaking'. Then one of the paramount chiefs said, 'I'm sorry, Helen is a female chief of Buka so she has the same power as we chiefs here, so she can stand up, and don't you people say bad things about her'. In addition to being a chief, Helen's clan was well known in that area and she had relatives there. If it had been an ordinary woman who asked to stand up while the chiefs remained seated, they would have asked for a pig as compensation. Helen was able to stand up to deliver her talk, but the other volunteers could not. When they did a role-play, they had to move away from where the people were seated so that they were not looking down on the chiefs. 
Another result of this incident was that Leitana Nehan met Fidelis Dana, one of the negotiators who went to the Dios. He later became a board member of Leitana Nehan. When Helen and her friends left the village that evening, they went on to conduct another awareness program in another village. It was dark, and they travelled by wooden canoe with no outrigger through a swamp, while the volunteers walked through the swamp alongside them, steadying and guiding the canoe.

As well as undertaking monitoring visits, the central office staff were organising activities to promote peace throughout the province. Leitana Nehan held a meeting of Bougainville women to gather information and discuss weapons disposal (Stage III of the peace process), views on the imminent withdrawal of the Peace Monitoring Group (PMG), and women's participation in the peace process, including constitutional reform (LNWDA 2003b). Over 200 women participated in this meeting to advance women's role in decisionmaking. They came from across all districts in Bougainville, including the no-go zone. Leitana Nehan also participated in two District Women's Council meetings with the Peace Monitoring Group and UN Observer Mission to discuss strategies to speed up weapons disposal, which was holding up the peace process (LNWDA 2003b). The disposal of all weapons was necessary before the election for autonomy could take place. These issues were related directly to the objectives of Phase 2 in that the removal of guns from armed groups was essential to reduce societal violence. Leitana Nehan participated in the North Bougainville Women's Leaders meeting in June 2003, with the UN Ambassador and an advisor from the New Zealand police, to discuss security leading up to the elections, weapons disposal and the training of more women for the Bougainville Transitional Police (LNWDA 2003b). In addition, Leitana Nehan met with the Bougainville Constitutional Committee (BCC) and UNICEF to lobby for the inclusion of clauses in the new constitution in support of women's and children's rights (LNWDA 2003b). Leitana Nehan, in partnership with UNICEF, also visited primary schools in the district to discuss women's and children's rights with teachers and parents. Leitana Nehan met with the families of police personnel to discuss domestic violence issues (LNWDA 2003b). 
A few infrastructure improvements took place in June-July 2003. By June 2003, the Leitana Nehan office in Buka had new toilet and showering facilities for staff and visitors, which at last met basic sanitation requirements for workers (LNWDA 2003b). A new electricity generator was installed in July to provide auxiliary power because the mains supply was very unreliable (LNWDA 2003b).

By July 2003, the teams had identified the communities that would provide the case studies for the project (LNWDA 2003b). In fact, by that time 15 out of 26 case studies were reported as nearing completion (LNWDA 2003b). In the case communities, the teams' emphasis was on promoting the formation of community-based organisations in the districts, using the training that teams and volunteers had received in organisational development and project planning. The teams helped build organisational capacity among existing and new community groups, by organising community groups and community-based organisations to write project proposals and apply for funding for their own local projects (LNWDA 2003b). The Tinputz team, for example, worked with the Tiop community to develop a water tank project, which secured funding through the PNG Community Development Scheme (CDS). In Siwai, the Tomongo Youth Group (a group of ex-combatants) received funding from NZ Aid for capacity-building training in community development and gender awareness. In Buin, the Kuhala Women's Group successfully developed a proposal for CDS funding to develop a small rice mill, and the Loait village also put in four 2,000 gallon water tanks and associated fittings. Funding for another rice mill was also obtained.

It is also interesting to note that the reporting format required by IWDA differed between the two phases of the project. In Phase 2 a set tabular format was used, providing less space for real stories from the field, which had been part of the reporting format adopted in Phase 1. Stories from the field are very useful to understanding what is actually happening on the ground with respect to community peacebuilding. The streamlining and formalising of the reporting process therefore actually reduced the richness of information being provided to the Leitana Nehan office in Buka and to IWDA. 
Leitana Nehan experienced a number of difficulties in the middle of 2003 (LNWDA 2003b). First, Radio Bougainville decided to charge the organisation a fee for using its service, a cost for which Leitana Nehan had not budgeted. In another temporary setback to the work being done by Leitana Nehan, a total blackout over a period of six weeks disrupted the radio program and other project activities being carried out through the Buka office.

A decline in law and order was evident in the middle of 2003 with police unable to uphold the law or protect women from violence (LNWDA 2003b). Leitana Nehan met with local police to address this issue and lobbied leaders and the government to rebuild the Court House so that law-breakers could be duly prosecuted before a magistrate, a move to reinstate the judicial system, which had been totally disrupted during the conflict. Leitana Nehan representatives met with a joint Law and Order Committee from New Zealand Aid and AusAID to discuss law and order issues in Bougainville. The NGO reported an escalation of violence against women and called for laws and action by the police and the judiciary to reduce problems associated with alcohol abuse in society (LNWDA 2003b). Violence against women was increasing despite the many awareness workshops run by groups such as Leitana Nehan to reduce violence in postconflict Bougainville. These interactions with the police, the PNG government and bilateral aid agencies indicates how Leitana Nehan was willing to move outside its NGO role as project manager to deal with issues that were directly related to its core business of standing up for women's rights and the elimination of violence against women. Specifically, however, this reflects the understanding that the SCP project will be more successful if the police and the judiciary are able to carry out their proper functions in society.

During the middle months of 2003, Leitana Nehan continued its own organisational development and energetically engaged with bilateral aid, international and civil society agencies to build a more peaceful Bougainville (LNWDA 2003b). For example, Leitana Nehan was networking with international NGOs such as UNICEF, World Vision and Caritas, as well as with the Peace Monitoring Group and the United Nations Observer Mission in Bougainville (UNOMB). 
Furthermore, it participated as a prominent player in meetings of the local Bougainville Alliance of Community Development Agencies (BACDA) (LNWDA 2003b).

During 2003, Leitana Nehan started working on a new strategic plan for 2004-07, with the assistance of an independent consultant based in Fiji, Colleen Taylor-Peacock (LNWDA 2003b). It also met with representatives from New Zealand Aid and AusAID to discuss future development assistance funding. The organisation was also increasingly recognised as a key agency for peace and advocacy in the region. For instance, Leitana Nehan was officially recognised for its peace work within Bougainville when it received an award at a ceremony in Arawa from the Peace Monitoring Group before it departed in July (LNWDA 2003b).

The middle of 2003 was a precarious period for peace workers in Bougainville because they were all concerned about whether armed violence would break out soon after the PMG left the country. One of their concerns was that guns disposal had not proceeded as planned in the Bougainville Peace Agreement. Although the Bougainville Resistance Forces (BRF) had surrendered their guns readily in accordance with the peace plan, it seemed that certain pockets of BRA were still reluctant to part with their weapons (LNWDA 2003b). The fear was that reluctance by certain BRA groups to disarm would prompt the resistance movement to rearm and the whole peace process would consequently be set back considerably. It was under these politically unstable circumstances that Helen was invited by the United Nations to attend the Third Biennial Conference on Small Arms. Unfortunately, communication problems between the PNG government and the Bougainville administration delayed the passage of funds and as a result the trip did not eventuate. Nevertheless, Leitana Nehan continued to campaign for weapons disposal and was subsequently invited to a negotiation meeting to discuss weapons disposal strategies (LNWDA 2003b).

An opportunity finally arose in the middle of Phase 2 to provide basic counselling training to a number of people in Bougainville, in line with Leitana Nehan's SCP aims. The Fiji Women's Crisis Centre conducted a training course on basic counselling skills for 42 
participants (24 women and 18 men) in Buka in August 2003 (LNWDA 2003b). Of the 42 participants, 26 were Leitana Nehan volunteers, some of whom were attending the course to refresh the basic skills acquired through earlier training and experience in the field. The completion of this training meant that all the Leitana Nehan teams comprised trained counsellors and some teams an assistant counsellor as well. The newly acquired skills helped teams deal with the increasing demands for counselling, particularly among victims of violence and rape, in districts across Bougainville. Violence escalated sharply during the second half of 2003, with increases in rapes, fights, murders and domestic disputes reported by Leitana Nehan teams and in police caseloads (LNWDA 2003b). The teams in the field were reporting back that women were now more willing to speak out against violence, report violent incidents and stand up for their rights confidently when faced with violence, than prior to SCP (LNWDA 2003b). For example, one woman who came to an early workshop was very shy, but she went on to become a Leitana Nehan team leader. In 2004, she was walking to visit a school in her new capacity as District Women's Facilitator, working with education inspectors, when she was stopped by some men who accused her of breaking custom by speaking out publicly and taking a leadership role. However, she countered that she was not taking over their leadership role, but just giving relevant information to parents and communities about how they can rebuild the schools themselves instead of waiting for the government to provide funds. This instance reflects the increase in women's confidence, and is in large part a positive reflection on Leitana Nehan's work to empower women and prevent the escalation of violence.

In the second half of 2003, the Bougainville Transitional Team invited Leitana Nehan to work with women's groups across Bougainville to put forward a position on weapons disposal (LNWDA 2003b). This was in preparation for the joint meeting of representatives including the PNG government, the Bougainville People's Congress and the UN Observer Mission to negotiate final terms and conditions for autonomy before an election date was set. The meeting was to take place on 9 September 2003. Leitana Nehan, in its advocacy role, was 
lobbying for 10 women (five from the North and five from the South) to participate in these proceedings in order to ensure that women's views and broader community views on weapons disposal were represented at the highest levels.

In September 2003, Leitana Nehan organised and ran a special training course for institutional leaders in the area of conflict transformation over two five-day periods (LNWDA 2003b). A total of 73 people enrolled in this training course ( 45 men and 28 women). The training was well attended and over-enrolled, as the course had initially been planned to accommodate only 40 participants. Participants included nurses, police personnel, teachers, school principals and magistrates. Community feedback following the training indicated that the police had made a commitment to improving the way that they dealt with cases of violence in relation to women's rights and children's rights (rape, incest, domestic violence, sexual harassment). They were also more willing or less afraid to take cases to court. For example, the community was able to convince the police to detain two men charged with rape for a lengthy period in order to maintain community safety (LNWDA 2003b).

\section{Box 5.2 Healing communities in the mountains of Suir Fabian Kotsin}

We started in Tekokni community. It's right up in the Suir area, in the mountains. They are a bit far from the main road. You have to climb up past Dios. We went up there and stayed there. Many people had realised that homebrew was causing a lot of fights. There was one woman from that community, who was a nurse, Mrs Tave, who was in our team, so we were able to work closely with the people there. They didn't know about rape and incest or the problems caused by homebrew.

When we did the awareness program, the chiefs were really enthusiastic about the homebrew issues. Everyone came and we were sitting there talking to them. It was the first time they had heard about women's rights. Then the women began to stand up for themselves. There's one area up there, Arabia, and one thing that happened there as a result of our homebrew awareness program was that the chiefs banned all the homebrewing. The paramount chief was Thomas. They completely banned homebrew making and consumption. All alcohol was banned at that time. If you were found drinking, they'd punish you by making you cut the grass in the school. 
Leitana Nehan was also able to extend its work beyond the local level by training community leaders and government agency personnel who were in a position to address violence in society more broadly. The government and community will play a crucial role in achieving Leitana Nehan's SCP goal of reducing societal violence across Bougainville. Leitana Nehan is an excellent example of a peacebuilding NGO actively engaging the community, civil society and state agencies in bringing about desired social change. The organisation has led the way in demonstrating how civil society groups can work with community and government support to rebuild a society following conflict.

Towards the end of 2003, reports of firearms being produced in public around Buka surfaced, the post-conflict administrative and commercial centre of Bougainville, at a time when the entire district was meant to be completely free of weapons. Specific reports in this period suggested particular groups' use of weapons was prompting other groups to consider rearming by purchasing weapons illegally from outside Bougainville (LNWDA 2003b). In response to these problems and the general escalation of violence, Leitana Nehan rallied the support of 400 women (LNWDA 2003b) and staged a peace march. ${ }^{5}$ The women specifically called for completion of weapons disposal in line with the UN-led peace process; reconvening of the courts in Buka to hear the hundreds of outstanding cases; implementation of existing laws on rape, incest and child abuse; a total ban on the illegal brewing of alcohol; and maintaining a state of peace in Bougainville.

All these messages were reinforced on the Leitana Nehan radio program that was broadcast across Bougainville every week. Moreover, all of the issues raised were of great importance to the success of the SCP project. The protest organised by Leitana Nehan expresses the activist role that it can play as a civil society agency in promoting non-violence and in highlighting the fact that taking up weapons again would derail the peace process and undermine the work carried out by peace-makers and peace-builders. As a women's development agency, it was capable of promoting the concerns of women in Bougainville, who have marched for peace and disarmament before 
and are widely recognised as important peace-makers in the community.

In the remaining months of Phase 2, between November 2003 and February 2004, Leitana Nehan concentrated its efforts on writing a proposal for a new project that would follow SCP, to be undertaken with New Zealand Aid and UNICEF (LNWDA 2003b). ${ }^{6}$ Otherwise, the organisation spent most of its time during this period completing Phase 2 by endeavouring to meet its targets for community development, counselling, monitoring, awareness workshops and the case study visits, as well as finalising reporting requirements. Leitana Nehan ran a Community Development Training (CDT) workshop for 12 community leaders ( 9 men and 3 women) from across the districts. The workshop ran for five days from 3-7 November 2003. In its final workshop in Phase 2, Leitana Nehan conducted a joint awareness exercise for police personnel and health workers on 'violence against women and the law'. Women's rights and children's rights were the main issues raised during the workshop (LNWDA 2003b). These last two workshops concluded the community consultation part of Phase 2 in view of empowering women and men to work together to end the violence in Bougainville.

\section{EVALUATION OF SCP PHASE 2}

At the end of SCP Phase 2, an independent assessor evaluated the project to determine how well objectives had been met and the extent to which the expected social outcomes had been achieved. Elizabeth Cox found during the evaluation that women with a close association with Leitana Nehan were more likely than not to be vocal about issues relating to violence against women and equity for women in leadership roles (Cox 2004b). According to Cox (2004b), the SCP project had successfully addressed the violence in society through awareness workshops and interactions with local communities. The field activities carried out by the Leitana Nehan teams positively affected the personal lives of many individuals and families-over 50 per cent of those consulted at the community level felt that the project had reduced the incidence of wife beating and homebrew consumption. The project had facilitated the participation of women in general, young people in 
particular, in examining their social problems. In addition, a number of team leaders and community representatives reported significant reductions in both homebrew production and alcohol-related conflict among communities in which the Leitana Nehan teams had been active. Community action to surrender arms and the equipment used to brew alcohol was widespread.

A significant proportion of men and women interviewed during this evaluation process had received some kind of direct training through Leitana Nehan, and more than half these people affirmed Leitana Nehan's importance in making a real difference to their lives (Cox 2004b). According to Cox (2004b), SCP made a number of important contributions to the peace efforts. First, it contributed to building a new values system in Bougainville based on human rights and social justice. Second, community leaders (chiefs, teachers, hospital staff, magistrates, police) held the organisations' grassroots activities to promote conflict transformation in high regard. Third, SCP had facilitated 'active citizenship' among women and men in Bougainville through membership and involvement in local community-based organisations, local governance instruments (committees and boards, the constitutional reform group), community service institutions (schools, hospitals and clinics), and partnerships with other civil society organisations in peace and development movements. Fourth, SCP contributed to transformation of individual's lives by, for instance, empowering men to move away from alcohol abuse, become committed fathers and responsible husbands, and by improving people's spiritual outlook, all of which contributed to enhancing the economic well-being of families (Cox 2004b).

Although counselling was an important part of the project, Cox found it difficult to evaluate this aspect of SCP due to the sensitive nature of the work. Nevertheless, community leaders, including chiefs and teachers, counted the Leitana Nehan counsellors as allies. All communities visited during the evaluation of SCP stated that Leitana Nehan counsellors had contributed much to conflict resolution and transformation in the districts (Cox 2004b).

In general, Cox's (2004b) observations amounted to a positive evaluation of how the SCP project had contributed to human/social 
development and to strengthening civil society across post-conflict Bougainville. The leaders of the Leitana Nehan teams showed commitment to community education and empowerment. Community leaders were impressed by the broad experience of the Leitana Nehan team leaders, who were able to wear many different caps in playing their part in community empowerment. This diversity helped the team leaders work cooperatively with other field-based organisations such as the Peace Foundation Melanesia. They were also able to build and maintain successful community alliances through effective networking and hence were in a strong position to facilitate local activities and contribute on multiple fronts beyond their immediate duties in the SCP project (Cox 2004b).

In evaluating Leitana Nehan's role in empowering women and raising their standing in society, Cox (2004b) identified a number of cases that reveal how this had changed opportunities for women. These include the recruitment of a number of women into the new police force in Bougainville; the appointment of three women representatives to the Bougainville Consitutional Committee, the body responsible for drafting a constitution for the newly-autonomous region; the demonstration of women's leadership capacities in Leitana Nehan and the willingness of men to work under women leaders; ${ }^{7}$ and the education and mobilisation of women to participate in a new society, speak out for their rights and protest against violence.

Leitana Nehan was recognised in 2004 as an important actor in conflict transformation when it was awarded the runner-up prize at the Fourth Pacific Human Rights Awards for outstanding work in peace and reconciliation advocacy and for the promotion of human rights for women and children in Bougainville during times of war and peace (Cox 2004b). Leitana Nehan's excellent regional and global networking had enabled it to integrate local action, global thinking, learning and solidarity, greatly improving its effectiveness, a result amply demonstrated by the successes of the SCP project (Cox 2004b). Leitana Nehan now has the capacity to build peace across Bougainville though 13 district-based teams, a trained volunteer base of over 90 committed people, and many more enthusiastic community-based representatives working alongside the teams to bring peace to their 
communities. Leitana Nehan has considerable capacity to continue its work in directing people's emotions and actions in positive ways, changing attitudes towards eliminating violence against women, promoting greater equity for women in society and strengthening the community base through popular and informal education that focuses specifically on building core values and principles for personal development and peaceful coexistence (Cox 2004b).

\section{CONCLUSION}

Cox's (2004b) evaluation of the SCP project illustrates clearly how much Leitana Nehan achieved over a few years. However, a great deal of humanitarian, human rights and social development work is yet to be completed in Bougainville to ensure that the region moves to a new era of autonomy. In other words, Leitana Nehan's violencereduction work needs to be complemented by development opportunities that will help Bougainville establish a viable economy. Leitana Nehan's teams must also extend their outreach activities and violence-reduction work to the numerous villages of Bougainville that they could not reach within the SCP project's timeframe. Areas within the no-go zone and the western parts of Bougainville in particular will require assistance in forthcoming years. Much of this work will involve counselling and violence-awareness workshops.

Regarding Leitana Nehan and its future development activities, three support programs under SCP showed great potential for further development. These include the radio program, which worked well in disseminating information and complementing the organisation's outreach activities; the counselling service, which was able to deal with hidden but sensitive violence issues in society; and the theatre troupe, which was able to reach people in the community who may not have otherwise come forward to report particular incidents of violence against women and children. These programs worked in concert to consolidate the teams' activities. ${ }^{8}$

The second phase of the SCP project concentrated much time in engaging with government agencies, community leaders and other local and international civil society organisations to reduce violence in society. In addition, Leitana Nehan was actively involved in 
promoting women's role as leaders and politicians in support of 'good governance' in Bougainville during the autonomy period. It also paid careful attention to planning for its future as an NGO by developing a strategic plan and writing project proposals that built on their strengths following SCP (LNWDA 2003b, 2004). The SCP project could function as a springboard for Leitana Nehan, helping it launch new projects and carry on the peace-building work commenced during SCP, which provided experience in project management and implementation as well as in the delivery of desired social outcomes in the context of post-conflict recovery.

Ultimately, the success of Phase 2 lies in the extent to which local communities have gained the capacity to address their social problems independently, organise themselves to secure funds, and gain skills through local CBOs. Many of the case study communities in Phase 2 were moving in this positive direction. A mechanism to support these new CBOs for several years following their establishment would be useful, and this is a role that Leitana Nehan could continue to perform given sufficient funding. Furthermore, the work that Leitana Nehan has commenced in local communities during SCP needs to be extended to cover the majority of villages on Bougainville in order to avoid pockets of violence prevailing or spreading to other areas. Additional funding would enable this grassroots anti-violence movement to grow so that many more local communities in Bougainville can benefit from the peace-building activities undertaken by Leitana Nehan. The expectation is that more funding will be available during the period of autonomy to extend peace-building activities in the region. Peace-building is the necessary first step towards building community capacity for socioeconomic development in Bougainville. Little can be achieved without funds to implement projects such as SCP in order to set up the necessary peaceful preconditions for economic development.

\section{NOTES}

In terms of gender awareness, LNWDA sees a need for men to accept women as equal partners in all areas of development, in finding a lasting solution for peace and in ending the cycle of violence in Bougainville society following the crisis. The 
organisation acknowledges the special place that women have in Bougainville, which is directly related to the matrilineal systems that exist in most parts of Bougainville (LNWDA and IWDA 2001).

2 Leitana Nehan sent several of its staff for professional development training. For example, Kris Hakena participated in a non-violence and peacebuilding workshop in India (2001), and Bianca Hakena attended a counselling workshop (AWAYS) in Thailand (2002).

3 For many and varied reasons, including distance, access and transport costs, it seemed relatively difficult for Leitana Nehan to work regularly in the western districts of Bougainville.

4 Trainers from Fiji Women's Crisis Centre (FWCC) in Suva conducted a basic counselling skills workshop in Buka for 42 people in August 2003, providing an opportunity for a number of team counsellors and community leaders to gain basic training in counselling (LNWDA n.d.). Helen Hakena acted as a co-facilitator during this training. Funding for the counselling training in 2001 and 2003 came from New Zealand Aid rather than the SCP budget.

5 The Peace March in Buka featured in two newspaper articles printed in the PostCourier in Papua New Guinea. The first article on 10 November reported on the women's protests and the second article on 27 November was about the calls by Bougainville women to destroy weapons.

6 Leitana Nehan was successful in gaining funding from New Zealand Aid for a followup to SCP, which concentrated solely on counselling. Again, Leitana Nehan has generated its next stage by building on the strengths of their previous experience.

7 The executive director of Leitana Nehan, Helen Hakena, provides an ideal model of a woman leader. Ms Hakena was publicly supported by a male deputy, George Lesi, who had been the province's chief administrator in the past, and her husband, Kris Hakena, who is a prominent businessman and the chief of his clan on the island of Buka. Furthermore, many public servants and government officials supported her as well. These examples illustrate public respect for a woman leader and how women and men can work well in partnership.

8 All of these support programs are active in the new SCP project that is underway. 